\title{
ASSESSMENT OF THE QUALITY OF PUBLIC HOSPITAL HEALTHCARE SERVICES BY USING SERVQUAL
}

\author{
Đurđana Ozretić Došen ${ }^{1}$, Vatroslav Škare ${ }^{1}$, Vesna Čerfalvi ${ }^{2}$, \\ Željka Benceković ${ }^{2}$ and Tanja Komarac ${ }^{1}$
}

\begin{abstract}
${ }^{1}$ Marketing Department, Faculty of Economics \& Business, University of Zagreb, Zagreb, Croatia; ${ }^{2}$ Sestre milosrdnice University Hospital Centre, Zagreb, Croatia
\end{abstract}

\begin{abstract}
SUMMARY - Hospital healthcare service quality measurement represents an important approach for advancing healthcare systems. This paper presents preliminary results of a research on the quality of healthcare services provided by a large, public, university hospital centre in Croatia, based on the Gaps Model of Service Quality and the SERVQUAL instrument. The importance of particular service quality dimensions was analyzed, as well as the gaps between patient perceptions and expectations of healthcare services provided by 18 departments of the university hospital centre. Results revealed the gaps that exist at the level of the university hospital centre as a whole, showing the size variations in different service quality dimensions. The management of the university hospital centre should improve healthcare service quality in all dimensions by paying particular attention to the 'responsiveness' and 'tangibility', where the largest gap was identified.
\end{abstract}

Key words: Service quality, Healthcare; Hospital; SERVQUAL; Transitional country; Developing country; Croatia; Sestre milosrdnice University Hospital Centre

\section{Introduction}

The existing evidence shows that assessment of the healthcare service quality in transitional and developing countries has been traditionally and for a long time based on professional standards ${ }^{1-3}$. However, over the past two decades, and especially due to the high growth rate of the healthcare industry in these countries in recent years ${ }^{4}$, patient perception of the healthcare services provided has emerged as an important quality indicator and as such represents a valuable approach for measuring and improving healthcare organization performance.

Hospitals are at the top of healthcare systems, their share in healthcare budgets is significant (e.g., in European countries accounting for $50 \%-70 \%$ of the bud-

Correspondence to: Đurđana Ozretic Došen, PhD, Marketing Department, Faculty of Economics \& Business, University of Zagreb, Trg J. F. Kennedyja 6, HR-10000 Zagreb, Croatia

E-mail: dozretic@efzg.hr

Received March 7, 2019, accepted September 12, 2019 get), and most often they represent the central part of the healthcare reform processes. Furthermore, hospitals are professionally managed; pharmaceutical and technological advances in their practices, as well as commitment to evidence-based practices, point to a conclusion that services provided by hospitals can significantly affect the health of the population ${ }^{5}$. Therefore, service quality measurement and implementation of safety ${ }^{6}$ principles in hospitals (and other healthcare institutions) represent an essential way for improvement of the overall healthcare systems in the countries that are going through major economic and managerial transformations, such as the Republic of Croatia. Stimulating improvement of the healthcare service quality is one of the strategic goals of the National Strategy for Health Care 2012-2020 in the Republic of Croatia .

Sestre milosrdnice University Hospital Centre in Zagreb (below, SM UHC) is one of the oldest and largest healthcare institutions in the Republic of Croatia, which besides healthcare performs activities of 
medical education and scientific research. SM UHC admits over sixty thousand inpatients and carries out about one million different healthcare services annually. It maintains its reputation and significance for over one hundred and seventy years, nurturing good tradition of the Croatian medicine with patient in the center of all activities and events, but also following the trends of modern medicine and requirements of the social environment. The SM UHC mission is to provide top quality healthcare services to patients along with development of all healthcare activities. The development strategy highlights the quality of healthcare services and its improvement as the foundation of the SM UHC management aimed at meeting the needs of all stakeholders, i.e. patients, staff, citizens, and society as a whole. More specifically, improvement and further development of the quality standards in the SM UHC include humanity, ethics, expertise and professionalism of all employees; patient and his/her family as the central part of the process; development of an environment that promotes culture of quality; development of innovative processes and excellence; development of scientific research in the field of healthcare and use of evidence-based knowledge, as well as the efficiency and effectiveness of all processes.

This paper describes the research based on the methodology of the Gaps Model of Service Quality and SERVQUAL instrument ${ }^{8}$, which was conducted as an initiative directed to improvement of the hospital healthcare service quality in the SM UHC. The objectives were twofold: firstly, to investigate the level of hospital healthcare service quality from the patient perspective and operationalized as a difference between perceived performance and patient expectations; and secondly, the aim was to identify the strengths and weaknesses of the existing level of hospital healthcare service quality in order to identify the areas and elements requiring improvement.

The paper is organized as follows: after the introduction, a brief literature review focusing on service quality measurement and using the Gaps Model of Service Quality and SERVQUAL instrument in a healthcare context is presented. The research methodology is described in the next section; and research results are summarized and analyzed. The main findings, research limitations, implications for theory and practice are presented in the concluding section.

\section{Methods}

\section{Approaches and methods for service quality measurement in hospital healthcare}

In healthcare services, the relationship between providers (physicians and other healthcare professionals) and customers (patients) is built on shared intimacy and is specific in many ways. In rare cases of other service types, there is such trust in the provideruser relationship as that expressed by most patients towards the physician and medical staff 9 . Contacts between physician, medical staff and patient represent critical service encounters and decisive moments. Healthcare professionals perform very complex activities that also require a high degree of patient involvement in service co-creation and delivery, as well as mutual collaboration among medical staff. Mistakes, irresponsibility, and negligence are not compatible with occupations in healthcare service delivery. The decision to use a healthcare service is transferred directly from patient to physician and medical staff, and since they are in direct and intense contact, the patient refers his/ her satisfaction (or dissatisfaction) with the service quality and the system to the medical staff.

As a specific type of healthcare, hospital services fall into the category of the existentially needed, unexpected, unwanted, and unpredictable service. Patient involvement and the degree of contact between him/ her, physicians and medical staff are extremely high. The patient is not skilled, does not have the knowledge needed to diagnose and treat. In addition, critical features of these services are a high-perceived risk, extreme trust in the provider, and a high need for safety.

The healthcare sector has become preoccupied with quality issues, which play an important role in determining how patients perceive the level of healthcare services provided. As stated by O'Connor et al. ${ }^{10}$, the concept of quality of healthcare services is constantly advancing and transforming depending on the interest and the level of involvement of medical staff, patients, financiers and lawmakers. Numerous factors that determine the quality of healthcare services (such as the access and effectiveness, ability and willingness of medical staff, the speed of providing services, the appropriate medical equipment, etc.) are difficult to standardize and measure ${ }^{11}$. Raposo et al. ${ }^{12}$ have emphasized the influence of the healthcare service quality dimensions on patient satisfaction and have proved that the 
perceived quality, both technical and functional, contribute to the process of patient satisfaction.

The conceptual model that links the context of quality in hospitals with their market orientation and organizational performance was developed and tested by Raju and Lonial ${ }^{13}$; they found the quality and market orientation, through synergetic relationships, to have a significant impact on hospital performance. Carman ${ }^{14}$ points to two problems; firstly, the one of understanding the complexity of the relationship between different technical attributes of hospital healthcare services (e.g., nursing care, physician care, outcome of hospitalization) and affective dimensions of hospital stay, which together form patient perception of the overall quality; and secondly, how these two types of attributes or dimensions are combined in patient attitude. A large study conducted by Aiken et al. ${ }^{15}$ in 12 different countries has revealed how patient safety, satisfaction, and quality of hospital healthcare are linked to the hospital work environment and consequently suggests that improvement of hospital work environment might lead to the improved perception of the hospital healthcare service quality.

Scientific literature from both marketing management and quality management shows that much attention has been devoted to the research of the approaches and methods of service quality measurement. Seth et al. ${ }^{16}$ examined 19 service quality models, pointing to their characteristics, linkage between them, and the need for further development. In conducting an extensive literature review, Castle et al. ${ }^{17}$ examined 59 studies providing information on 54 instruments used for researching hospital patient perceptions of healthcare; they have concluded that despite a diversity of research instruments, the salience of use of survey instruments has increased. Although there are research studies (e.g., Shemwell and Yavas ${ }^{18}$, Musa-Juroš et $a .^{19}$ ) where the authors tried to propose and test a scientifically based model and/or an appropriate scale to measure the specific quality of hospital healthcare services, a unique method and instrument have not yet been developed.

\section{Assessing hospital healthcare service quality using SERVQUAL instrument}

The Gaps Model of Service Quality and its SERVQUAL instrument is among the best known and most commonly used multidimensional models for measur- ing service quality. The model foundation is the definition of service quality as comparison between what is provided and what was expected, and establishing and understanding the gaps occurring in the service delivery process $^{20}$. SERVQUAL has been applied to measure the quality of various service types, different healthcare services included ${ }^{21}$ for more than 30 years.

Hospital services as a specific type of healthcare services require an extremely high degree of contact between medical staff and patients, as well as a high degree of patient involvement in the process of service delivery. Hospitals are the healthcare institutions that depend almost entirely on the economic welfare and confidence of the community they serve. Considerable research efforts have been dedicated to the quality of healthcare services in hospitals in developed countries $^{22-26}$. However, evidence and knowledge about patient perceptions of hospital service quality in developing countries are limited. Interestingly, most research was done in the Asian and African countries ${ }^{27-32}$. Research on hospital service quality from the patient perspective in European developing countries, to the best of the authors' knowledge, is scarce. Besides two studies from the settings of Turkish hospitals (public and private) conducted by Taner and Antony ${ }^{33}$ and Sahin et $a l^{34}$, and one from Albanian public hospital undertaken by Kalaja et al. ${ }^{35}$, there are no empirical contributions dedicated to the measurement of the hospital healthcare service quality in developing Central and Eastern European, South Eastern European and/or Baltic countries. The existing research on patient perceptions of healthcare service quality in these countries has concentrated on applying SERVQUAL scale in the research of the quality of healthcare services provided by primary healthcare institutions (with special emphasis on public sector healthcare institutions) in Croatia ${ }^{36}$, state-run student policlinics in Serbia ${ }^{37}$, and public gynecologic healthcare services in Romania $^{38}$. Therefore, researching hospital service quality from the patient perspective in developing countries within the European context presents an actual topic, which has not been researched so far.

\section{Research setting, research instrument, sampling and data collection}

In line with the Gaps Model of the Service Quality, the underlying hypothesis of the research was that, despite the high ratings of the perceived quality of 
hospital services in SM UHC, there would be different gaps across service quality dimensions at the level of the SM UHC as a whole, and across different departments of the SM UHC.

All necessary approvals from the institutional Ethics Committee of the SM UHC were obtained before the beginning of the field research. Primary data were collected by surveying patients having used hospital services in the SM UHC. The SERVQUAL instrument was applied. The questionnaire was modified by adding two statements to the original 22 ones, regarding food served to patients and physical appearance of the clinical hospital centre. The level of patient agreement with the 24 statements (for both expectations and perceptions) was measured by 5 -point Likert scale (1 - totally disagree to 5 - completely agree). Prior to data collection, the instrument was pretested on a convenience sample of 20 patients. Minor changes related to the clarity of three statements were made. The questionnaire consisted of two main sections. In the first one, patients were asked to express the level of their agreement with the 24 statements regarding their expectations from hospital services. In addition, they were asked to divide 100 points among the five quality dimensions of hospital services, according to how important each dimension was to them. At the end of the first section, 4 closed type questions about patient demographics were included. The second section consisted of another group of 24 statements dedicated to patient perceptions of the hospital services provided; they were asked to express the level of their agreement with the perceived hospital service quality.

The population were all patients having utilized hospital services at SM UHC, and sample frame included those hospitalized at SM UHC in the period from October 2016 to April 2017. The intended quota (by departments) sample was used, consisting of 630 patients who were selected based on convenience and availability, and who voluntarily accepted to participate in the research. The questionnaire was properly completed by 564 patients; 66 questionnaires were invalid and therefore excluded from analysis.

In order to collect data from field research, staff members from the Quality Department of SM UHC introduced medical staff in all departments with the nature and goals of the study, before its implementation. Furthermore, they talked to patients, explaining the motives and purpose of the research. Patients who agreed to participate were over 18 years of age and had to fill-in the questionnaire by themselves, with the exception of the Department of Pediatrics, where parents took part instead of children. In addition, both the staff members from the Quality Department and medical staff in departments assisted the more serious patients who had difficulties with filling-in the questionnaire. Completing the questionnaire was done in two phases, as follows: 1) measuring expectations, the importance given to the individual dimensions of hospital service quality and demographics - upon patient admission to the SM UHC; and 2) measuring perceptions of the hospital services provided - at patient discharge from the SM UHC.

\section{Results}

The data collected from 564 questionnaires were analyzed by using the MS Office Excel and SPSS software packages, with the results presented descriptively. Table 1 summarizes the profile of the sample. Most of the respondents were women $(n=312 ; 55 \%)$. The largest age cohort belonged to the 50-64 age group $(n=174$; $31 \%)$. According to the level of education, 321 (57\%) respondents had secondary and 190 (33\%) college/ university education.

The respondents were asked to grade the importance that each of the five dimensions (tangibles, reliability, responsiveness, assurance and empathy) holds for them in the assessment of hospital service quality. The importance/significance of individual service quality dimensions is shown in Table 2.

In their assessments of the quality of hospital services, respondents considered 'assurance' to be the crucial dimension. It includes confidence and discretion, physical safety, as well as freeing the patient from any suspicion or danger. The second most important dimension was 'reliability', involving consistency of execution and the ability of the hospital to perform the promised service reliably and accurately. It also refers to the accurate patient record keeping and service provision in a specific period. The third-ranking dimension was 'responsiveness', which implies that the hospital should have enough medical staff that is competent, ready and willing to provide quick service, and prompt and precise responses to patients. 'Empathy' was the penultimate dimension by importance. It concerns attentiveness to patient requirements, involving 
knowing the patient specific needs and requirements and providing individual attention to each patient. The least important dimension were 'tangibles', such as the appearance of physical elements - space, equipment and staff. This dimension includes the level of adaptation of hospital infrastructure to patients, and food service in the hospital, too.

\section{Table 1. Demographic profile of the sample $(N=564)$}

\begin{tabular}{|l|l|l|}
\hline Gender & $\begin{array}{l}\text { Number of } \\
\text { respondents }\end{array}$ & Percentage \\
\hline Fale & 252 & $45 \%$ \\
Female & 312 & $55 \%$ \\
\hline Age (years) & $\begin{array}{l}\text { Number of } \\
\text { respondents }\end{array}$ & Percentage \\
\hline $18-29$ & 54 & $10 \%$ \\
$30-39$ & 92 & $16 \%$ \\
$40-49$ & 89 & $16 \%$ \\
$50-64$ & 174 & $31 \%$ \\
$\geq 65$ & 155 & $27 \%$ \\
\hline Educational level & Number of & Percentage \\
\hline $\begin{array}{l}\text { Unfinished elementary } \\
\text { school }\end{array}$ & 6 & $1 \%$ \\
Elementary school & 47 & $9 \%$ \\
Secondary (high) school & 321 & $57 \%$ \\
College/university & 190 & $33 \%$ \\
\hline
\end{tabular}

Source: authors' calculation
Table 3 shows the unweighted and weighted gap between patient service quality perceptions and expectations according to SERVQUAL dimensions. The weighted gap is calculated from the scores of individual service quality dimensions with the number of points assigned to them according to their relative importance/significance.

Respondent SERVQUAL scores on all dimensions except for empathy were negative, meaning that patient expectations exceeded their perceptions. The perceived service quality was unsatisfactory, i.e. there was a gap (ranging between -0.37 and -0.05) on four service quality dimensions. The largest unweighted and weighted gap was observed on the 'responsiveness' dimension. Within that dimension, the gap concerning the statement about the sufficient number of medical staff in hospital was the largest, which is understandable given the current situation in public health service sector in Croatia. Due to the importance paid to that element by patients, the 'responsiveness' dimension recorded the largest single weighted gap. Four dimensions with negative gaps showed stability of rankings by gap size, regardless of weighting (Table 4).

It is evident from data in Table 4 that the least unweighted and weighted gap was observed on the 'assurance' dimension, meaning that patients felt highly confident and safe in the existing relationship between them and medical staff, which implies how irresponsibility, negligence and/or mistakes were not compatible

Table 2. Importance of individual hospital service quality dimensions to respondents $(N=564)$

\begin{tabular}{|l|l|l|l|l|l|}
\hline SERVQUAL model dimensions & Reliability & Assurance & Responsiveness & Empathy & Tangibles \\
\hline Importance of each dimension (\%) & 23.16 & 24.25 & 22.38 & 15.99 & 14.22 \\
\hline
\end{tabular}

Source: authors' research

Table 3. Unweighted and weighted gap between quality perceptions and expectations

\begin{tabular}{|l|l|l|l|l|l|l|l|l|}
\hline \multirow{2}{*}{$\begin{array}{l}\text { SERVQUAL } \\
\text { dimension }\end{array}$} & \multicolumn{4}{|c|}{ Unweighted gap } & \multicolumn{5}{c|}{ Weighted gap } \\
\cline { 2 - 9 } & Gap & Min & Max & SD & Gap & Min & Max & SD \\
\hline Tangibles & -0.34 & -0.57 & 0.10 & 0.29 & -0.05 & -0.08 & 0.01 & 0.04 \\
Reliability & -0.19 & -0.34 & 0.01 & 0.13 & -0.04 & -0.08 & 0.00 & 0.03 \\
Responsiveness & -0.37 & -1.05 & 0.02 & 0.40 & -0.08 & -0.24 & 0.00 & 0.09 \\
Assurance & -0.05 & -0.09 & 0.00 & 0.04 & -0.01 & -0.02 & 0.00 & 0.01 \\
Empathy & 0.10 & 0.04 & 0.23 & 0.07 & 0.02 & 0.01 & 0.04 & 0.01 \\
\hline
\end{tabular}

$\mathrm{N}=564 ;$ Min = minimal value Max = maximal value $\mathrm{SD}=$ standard deviation

Source: authors' research 
Table 4. Comparison of individual service quality rankings by the size of unweighted and weighted gap between quality perceptions and expectations

\begin{tabular}{|c|c|c|}
\hline \multirow[t]{2}{*}{ Gap size } & \multicolumn{2}{|c|}{$\begin{array}{l}\text { Dimension ranking by negative } \\
\text { gap size }\end{array}$} \\
\hline & Unweighted gap & Weighted gap \\
\hline $\begin{array}{r}\text { Minimum gap } \\
\uparrow \\
\text { Maximum gap }\end{array}$ & $\begin{array}{l}\text { Assurance } \\
\text { Reliability } \\
\text { Tangibles } \\
\text { Responsiveness }\end{array}$ & $\begin{array}{l}\text { Assurance } \\
\text { Reliability } \\
\text { Tangibles } \\
\text { Responsiveness }\end{array}$ \\
\hline
\end{tabular}

Source: authors' research

with the expectations patients had from the staff of SM UHC.

The only service quality dimension with positive gap (unweighted and weighted) was 'empathy'. The expectations of patients (who, in general, are not experts and do not have the knowledge needed to diagnose and decide about their treatment) were positively outperformed in terms of the perceptions that the medical staff of the SM UHC (who possesses the necessary knowledge and expertise) was willing to listen to patients and decide what was the best for the patient individually, according to their characteristics and specific health situations.

\section{Discussion and Conclusion}

The present research revealed that patient expectations were high in all dimensions of the service quality. Furthermore, for most dimensions of the perceived quality of the hospital service, patients gave high rating. Still, patient assessment of four out of five SERVQUAL dimensions was negative, which means that their expectations exceeded the perception of the actual service received. The smallest gap was observed on the assurance dimension, which was at the same time the dimension that was most significant to patients in their service quality assessment. Due to the specific nature of hospital services and high involvement of both patients and medical staff in the service delivery process, elements such as confidentiality, discretion, and physical safety may be assumed to have retained their importance in quality assessment. The research found the patient key dissatisfaction areas to be associated with 'responsiveness' and 'tangibles'. It suggests that patients witnessed deficiency in terms of an adequate number of professional human resources, i.e. medical staff working at the clinical hospital centre. They were not satisfied with the waiting time for service delivery and provision of the necessary information to them. Patient expectations related to physical appearance of the clinical hospital centre infrastructure (space, equipment, adaptation to patient needs) were higher than their perception of the service received, indicating the existence of a quality gap in the 'tangibles' dimension.

Study results corroborate previous findings ${ }^{26}$, revealing that although having a situation where the overall satisfaction with the service is high at the level of the university hospital centre as a whole, there are a number of areas where different dimensions of service quality could be improved, at the levels of the university hospital centre and its departments. Furthermore, results confirm that the valuable insights into the scope of necessary improvements can be revealed by monitoring and interpreting the level of the gap scores identified $^{33}$.

As in other studies dedicated to service quality measurement in healthcare, hospitals more specifically, conducted by using SERVQUAL instrument ${ }^{24}$, it may be concluded that SERVQUAL offers a useful approach for recognizing the patterns of patient expectations and perceptions across different hospital departments, which represents an essential input for future managerial decisions. Also, these results point to the fact found in the previously conducted research ${ }^{35}$, that in order to accomplish the goal of offering high quality hospital services, patients should be taken as the main actors in appraising and evaluating service quality.

Our results can be considered an indicative assessment of the quality of public hospital services. One of the research limitations was related to the type, size and structure of the sample. Consideration should also be given to the positive bias of respondents, as questionnaires were, although self-administered, filled-in in the hospital; and in the case of more severely ill patients, assistance by hospital staff was provided. Therefore, the results are highly indicative but cannot be generalized.

The contribution of the paper stems from the choice and handling of this particular topic, which is still underrepresented in the field of healthcare service research in the context of public hospital healthcare service sector in the European countries faced with 
significant economic and managerial transformations. As such, the research is in line with the call of Burgess and Steenkamp ${ }^{39}$ who advocate more academic research in transitional and developing countries in order to contribute to the advancement of science and practice by theory development, acquisition of meaningful data, and analysis of the data from these countries where more than $80 \%$ of the world population, i.e. consumers of different products and services, live ${ }^{40}$. The results of this study complement the existing knowledge with insights from the Croatian public healthcare service sector, and as such enable deepening the understanding of the hospital healthcare service quality.

As for the managerial implications in the context of the hospital clinical performance, it would be of substantial importance to implement an ongoing measurement of the degree of patient satisfaction with the provided service quality. Hospital managers should be by far more interested and receptive to the information provided by patients since this represents an appropriate and effective way to learn about patient expectations and to find consequently ways and approaches how to fulfill them. Open communication with patients, personal attention, and responsiveness to their feedback prove to help gain awareness about what their expectations are, and enable the right choice of the initiatives for service quality improvements, which will result in success. In this way, physicians, other healthcare professionals, administrators, i.e. all hospital employees who come in contact with patients, could also benefit from an in-house service quality orientation training, which would enable them to gain necessary awareness about patient expectations.

Furthermore, managers should also pay more attention to improving all dimensions of service quality, no matter how modest the available resources are. They need to invest continuous efforts to improve hospital conditions in general and especially by focusing on quality dimensions that are found to be highly specific to various hospital departments, in order to enhance service quality perceptions and patient ultimate satisfaction. Therefore, these research results provide information that may serve as a useful foundation and guideline for further activities and as an incentive to conduct longitudinal research of service quality, in order to be continuously aware of the areas requiring improvements. Continuous research would provide an opportunity to recognize trends in the development of hospital service quality in the public health service sector.

\section{References}

1. Leonard KL, Masatu MC. The use of direct clinician observation and vignettes for health services quality evaluation in developing countries. Soc Sci Med. 2005;61(9):1944-51. https:// doi.org/10.1016/j.socscimed.2005.03.043

2. Andaleeb SS. Service quality perceptions and patient satisfaction: a study of hospitals in a developing country. Soc Sci Med. 2001;52(9):1359-70. https://doi.org/10.1016/S0277-9536(00) 00235-5

3. Luck J, Peabody JW, DeMaria LM, Alvarado CS, Menon, R. Patient and provider perspectives on quality and health system effectiveness in a transition economy: evidence from Ukraine. Soc Sci Med. 2014;114(Aug):57-65. https://doi.org/10.1016/j. socscimed.2014.05.034

4. Meesala A, Paul J. Service quality, consumer satisfaction and loyalty in hospitals: thinking for the future. J Retailing Con Serv. 2018;40(Jan):261-9. https://doi.org/10.1016/j.jretconser.2016.10.011

5. McKee M, Healy J. The significance of hospitals: an introduction. In: Healy J, McKee M, editors. Hospitals in Changing Europe. Buckingham: Open University Press; 2002.

6. Šklebar I, Mustajbegović J, Šklebar D, Cesarik M, Milošević M, Brborović H, Šporčić K, Petrić P, Husedžinović I. How to improve patient safety culture in Croatian hospitals? Acta Clin Croat. 2016;55:370-80. https://doi.org: 10.20471/acc. 2016.55.03.04

7. Republic of Croatia Government, Ministry of Health, 2012 [Internet]. Nacionalna strategije razvoja zdravstva 2012.-2020. Available from: https://bit.ly/2F7tvN6 (in Croatian)

8. Parasuraman A, Zeithaml V, Berry LL. SERVQUAL: a multiple-item scale for measuring consumer perceptions of service quality. J Retailing. 1988;64(1):12-37.

9. Corbin CL, Kelley SW, Schwartz RW. Concepts in service marketing for healthcare professionals. Am J Surg. 2001;181 (1):1-7. https://doi.org: 10.1016/s0002-9610(00)00535-3

10. O'Connor S, Tring HQ, Shewchuk R. Perceptual gaps in understanding patient expectations for health care service quality. Qual Manag Health Care. 2001;9(2):26-42.

11. Campbell SM, Roland MO, Buetow SA. Defining quality of care. Soc Sci Med. 2000;51:1611-25.

12. Raposo ML, Alves HM, Duarte, PA. Dimensions of service quality and satisfaction in healthcare: a patient's satisfaction index. Serv Bus. 2009;3(1):85-100. https://doi.org/10.1007/ s11628-008-0055-1

13. Raju PS, Lonial SC. The impact of quality context and market orientation on organizational performance in a service environment. J Serv Res. 2001;4(2):140-54. https://doi.org/10.1177/ 109467050142006 
14. Carman JM. Patient perception on service quality: combining the dimensions. J Serv Mark. 2000;14(4):337-52. https://doi. org/10.1108/08876040010334565

15. Aiken LH, Sermeus W, Van den Heede K, Sloane DM, Busse R, McKee M, Bruyneel L, Rafferty AM, Griffits P, MorenoCasbas MT, Tishelman C, Scott A, Brzostek T, Kinnunen J, Schwendimann R, Heinen M, Zikos D, Sjetne IS, Smith HL, Kutney-Lee A. Patient safety, satisfaction, and quality of hospital care: cross sectional surveys of nurses and patients in 12 countries in Europe and the United States. BMJ. 2012;334:114. https://doi.org/10.1136/bmj.e1717

16. Seth N, Deshmukh SG, Vrat P. Service quality models: a review. Int J Qual Reliab Manag. 2004;22(9):913-49. https://doi. org/10.1108/02656710510625211

17. Castle NG, Brown J, Hepner KA, Hays RD. Review of the literature on survey instruments used to collect data on hospital patient's perceptions of care. Health Serv Res.2005;40(6):19962017. https://doi.org/10.1111/j.1475-6773.2005.00475.x

18. Shemwell DJ, Yavas U. Measuring service quality in hospitals: scale development and managerial applications. J Mark Theory Practice.1999;7(3):65-75. https://doi.org/10.1080/10696679.1 999.11501841

19. Musa-Juroš K, Mijoč J, Horvat J, Ilakovac V, Marković S, Racz A. Measuring healthcare quality - paradigm of MEDQUAL. Acta Clin Croat. 2018;57(2):235-42. https://doi.org/10.20471/ acc.2018.57.02.02

20. Zeithaml VA, Parasuraman A, Berry LL. Delivering Quality Service: Balancing Customer Perceptions and Expectation. New York: The Free Press, 1990.

21. Kilbourne W E, Duffy J A, Duffy M, Giarchi G. The applicability of SERVQUAL in cross-national measurements of health-care quality. J Serv Mark. 2004;18(7):524-33. https:// doi.org/10.1108/08876040410561857

22. Anderson E A. Measuring service quality at a university health clinic. Int J Health Care Qual Assur. 1995;8(2):32-7. https:// doi.org/10.1108/09526869510081866

23. Camilleri D, O'Callaghan M. Comparing public and private hospital care service. Int J Health Care Qual Assur. 1998; 11(4):127-33.

24. Wong JCH. Service quality measurement in a medical imaging department. Int J Health Care Qual Assur. 2002;15(5):206-12. https://doi.org/10.1108/09526860210437421

25. Laschinger HS, Hall L, M, Pedersen C, Almost J. A psychometric analysis of the patient satisfaction with nursing care quality questionnaire. J Nurs Care Qual. 2005;20(3):220-30.

26. Wisniewski $\mathrm{M}, \mathrm{W}$ isniewski $\mathrm{H}$. Measuring service quality in a hospital colposcopy clinic. Int J Health Care Qual Assur. 2005; 18(3):217-28. https://doi.org/10.1108/09526860510594776

27. Lam SKS. SERVQUAL: a tool for measuring patients' opinion of hospital service quality in Hong Kong. Tot Qual Manage. 1997;8(4):145-52.
28. Andaleeb SS. Service quality perceptions and patient satisfaction: a study of hospitals in a developing country. Soc Sci Med. 2001;52(9):1359-70. https://doi.org/10.1016/S0277-9536(00) 00235-5

29. Sohail MS. Service quality in hospitals: more favourable than you might think. Manag Serv Qual. 2003;13(3):197-206. https://doi.org/10.1108/09604520310476463

30. Al-Borie HM, Damanhouri AMSD. Patients' satisfaction of service quality in Saudi hospitals: a SERVQUAL analysis. Int J Health Care Qual Assur. 2013;26(1):20-30. https://doi.org/ 10.1108/09526861311288613

31. Li M, Lowrie DB, Huang C, Lu X, Zhu Y, Wu X, Shayiti M, Tan Q, Yang H, Chen S, Zhao P, He S, Wang X, Lu H. Evaluating patients' perception of service quality at hospitals in nine Chinese cities by use of the ServQual scale. Asian Pac J Trop Biomed. 2015;5(6):497-504. https://doi.org/10.1016/j.apjtb. 2015.02.003

32. Butt MM, de Run EC. Private healthcare quality: applying a SERVQUAL model. Int J Health Care Qual Assur. 2010; 23(7):658-73. https://doi.org/10.1108/09526861011071580

33. Taner T, Antony J. Comparing public and private hospital care service quality in Turkey. Leadersh Health Serv. 2006;19(2):110. https://doi.org/10.1108/13660750610664991

34. Sahin B, Yilmaz F, Lee KH. Factors affecting inpatient satisfaction: structural equitation modeling. J Med Sys. 2007;31 (1):9-16.

35. Kalaja R, Myshketa R, Scalera, F. Service quality assessment in health care sector: The case of Durres Public Hospital. Procedia Soc Behav Sci.2016;235(24):557-65.https://doi.org/10.1016/j. sbspro.2016.11.082

36. Ozretić-Došen Đ, Škare V, Škare T. Mjerenje kvalitete usluge primarne zdravstvene zaštite SERVQUAL instrumentom. Revija za socijalnu politiku. 2010;17(1):27-44. https://doi.org/ 10.3935/rsp.v17i1.900 (in Croatian)

37. Senić V, Marinković V. Patient care, satisfaction and service quality in health care. Int J Consum Stud. 2013;37(3):312-9. https://doi.org/10.1111/j.1470-6431.2012.01132.x

38. Purcărea VL, Gheorghe IR, Petrescu CM. The assessment of perceived service quality of public health care services in Romania using the SERVQUAL scale. Procedia Econ Finance. 26;6:573-85. https://doi.org/10.1016/S2212-5671(13)00175-5

39. Burgess SM, Steenkamp JBEM. Marketing renaissance: how research in emerging markets advances marketing science and practice. Int J Res Mark. 2006;23(4):337-56. https://doi. org/10.1016/j.ijresmar.2006.08.001

40. Steenkamp JBEM, Burgess SM. Optimum stimulation level and exploratory consumer behavior in an emerging consumer market. Int J Res Mark. 2002;19(2):131-50. https://doi. org/10.1016/S0167-8116(02)00063-0 
Sažetak

\title{
PROCJENA KVALITETE JAVNO ZDRAVSTVENIH USLUGA U KLINIČKOJ BOLNICI PRIMJENOM INSTRUMENTA SERVQUAL
}

\author{
Đ. Ozretic Došen, V. Škare, V. Čerfalvi, Ž. Benceković i T. Komarac
}

Mjerenje kvalitete bolničke zdravstvene usluge čini važan pristup unaprjeđenju zdravstvenog sustava. U radu se iznose preliminarni rezultati istraživanja o kvaliteti zdravstvenih usluga pruženih u velikom javnom kliničkom bolničkom centru u Hrvatskoj, temeljenom na Modelu jazova u kvaliteti usluge, a uz korištenje mjernog instrumenta SERVQUAL. Analizirana je važnost pojedinačnih dimenzija kvalitete usluge, kao i jazovi između percepcija pacijenata i njihovih očekivanja za zdravstvene usluge pružene u 18 klinika/zavoda. Rezultati pokazuju jazove koji postoje na razini kliničkog bolničkog centra kao cjeline te razlike u veličini jazova po dimenzijama kvalitete usluge. Uprava bolnice treba poboljšati zdravstvene usluge u svim dimenzijama kvalitete, a osobitu pozornost treba pridati dimenzijama odgovornosti i opipljivosti gdje su pronađeni najveći jazovi.

Ključne riječi: Kvaliteta usluge; Zdravstvo; Bolnica; SERVQUAL; Tranzicijska zemlja; Zemlja u razvoju; Hrvatska; Klinički bolnički centar Sestre milosrdnice 